\title{
Ultrastructural changes in the spermatogonia and spermatocytes of Poecilia reticulata during spermatogenesis
}

\author{
Roland Billard \\ I.N.R.A., Laboratoire de Physiologie des Poissons, Campus de Beaulieu, Rennes, France \\ et Station de Physiologie animale Jouy en Josas, France
}

\begin{abstract}
Summary. The structure of guppy (Poecilia reticulata) spermatogonia and spermatocytes has been studied using electron microscopy. The spermatogonia, situated at the apex of the seminiferous tubule, are almost all surrounded by a network of Sertoli cells; they have very diffuse chromatin and one or two large nucleoli. The cytoplasm contains relatively few organelles, although annulate lamellae are found. The mitochondria have few cristae and are concentrated at one pole of the cell; they are sometimes found with intermitochondrial cement. These spermatogonia are separated from each other, having no intercellular bridges or inclusion in Sertoli cells, and are relatively undifferentiated; they correspond to stem cells. The spermatogonia beneath the apex are organized into cysts. First-generation spermatogonia are more dense and heterogeneous, their nuclei becoming smaller and their chromatin becoming denser during successive generations. In spermatocytes, the synaptinemal complex exists as a modified form until metaphase. The concentration of organelles in the cytoplasm increases and the organelles become more diversified as spermatogenesis progresses. Many cytoplasmic bridges are observed (several per cell), indicating that the cells remain in contact after several divisions. These changes in germ cell structure have been related to some of the characteristic features of spermatogenesis in guppy, e.g. the large number of spermatogonial generations and the complexity of spermiogenesis.
\end{abstract}

Key words: Spermatogonia - Spermatocytes - Carbohydrates - Guppy - Electron microscopy

Spermatogenesis in poecilids has been studied by several authors and exhibits certain characteristic features (Vaupel 1929; Dulzetto 1933; Billard 1969 a, 1970a, b; Hurk 1973; Grier $1975 \mathrm{a}, \mathrm{b})$. The testis is composed of short seminiferous tubules radiating from a central testicular canal. At the periphery, the apex of the tubules is occupied by type A spermatogonia (GA) organized into cysts in which the entire process of spermatogenesis occurs, as in all the lower vertebrates. Fourteen spermatogonial generations have been found in the guppy, Poecilia reticulata (Billard 1969a), this being the largest number yet reported for vertebrates

Send offprint requests to: Roland Billard, INRA, Laboratoire de Physiologie des poissons, Campus de Beaulieu, 35042 Rennes Cedex, France
(Roosen-Runge 1977). The cysts in guppy are large and have the peculiar feature of moving along the seminiferous tubules as spermatogenesis progresses. At the completion of spermatogenesis, spermatozoa are released into the testicular duct. This type of testicular structure has been called tubular (Billard et al. 1982) or "restricted" (Grier 1981) as opposed to the more frequent type in teleosts which is termed lobular or "unrestricted". The final phase of cyst migration or spermiogenesis has already been described (Billard 1970a). The present paper concerns two points that have been little discussed: (1) the structure of spermatogonia in the apex and their relationship to somatic cells, and (2) the structure and organization of the spermatogonia and spermatocytes in cysts and changes in their nuclear and cytoplasmic compartments during the spermatogonial generations and meiotic prophase.

\section{Materials and methods}

The fish and their rearing conditions have been described (Billard 1969a). Testicular fragments or microdissected tubules were fixed for $30 \mathrm{~min}$ in a $4 \%$ solution of glutaraldehyde (0.1 M phosphate buffer, $\mathrm{pH} 7.25)$ and postfixed in a $2 \%$ solution of $\mathrm{Os}_{4}$ in the same buffer. Several crosssections were treated with phosphotungstic acid (PTA) to identify carbohydrate-like material; the tissues, fixed in glutaraldehyde, were embedded in glycolmethacrylate and the sections treated for $30 \mathrm{~min}$ with PTA in a $1 \%$ aqueous solution in normal $\mathrm{HCl}$. The technique for glycogen identification using periodic-acid-thiocarbohydrazide-silver proteinate (PA-TC-SP) has been described (Billard et al. 1973).

The size of various organelles was measured; maximal dimensions or mean values were obtained from about 50 measurements. The nucleo-mitochondrial ratio of André (1962) was established by planimetry on about 10 sections of various germ cells; type A spermatogonia (GA), type B spermatogonia (GB) in either early (G1-G7) or late (G8G14) stages (Billard 1969a), and spermatocytes in prophase or metaphase. Our observations are shown in Figs. 1 to 13 and a summary is given in Table 1.

\section{Results}

Spermatogonia in the tubular apex

Each of the spermatogonia in the tubular apex was almost completely surrounded by Sertoli cells (Figs. 1,2), the nu- 
Table 1. Summary of the evolution of some organelles in the germ cell during spermatogenesis (excluding spermiogenesis) in the guppy

\begin{tabular}{|c|c|c|c|c|c|}
\hline & \multirow[t]{2}{*}{$\mathrm{G}_{\mathrm{A}}($ apex $)$} & \multicolumn{2}{|l|}{$\mathrm{G}_{\mathrm{B}}$ in cysts } & \multicolumn{2}{|l|}{ Spermatocytes } \\
\hline & & $\mathrm{G}_{1}-\mathrm{G}_{7}$ & $\mathrm{G}_{8}-\mathrm{G}_{14}$ & prophase & metaphase \\
\hline Chromatin aspect & clear homogeneous & clear clusters & dense clusters & dense clusters & - \\
\hline Perichromatin granules & rare & + & + & + & + \\
\hline Interchromatin granules & + & + & + & + & + \\
\hline number & $1-2$ & $1-2$ & 1 & (1) & $?$ \\
\hline size, $\mu \mathrm{m}$ & 3 & 1 & 0.2 & $0.2-0.5$ & $?$ \\
\hline \multicolumn{6}{|l|}{ Cytoplasmic structures } \\
\hline \multicolumn{6}{|l|}{ Mitochondria: } \\
\hline Intercentriolar formation & + & + & + & + & $\bar{t}$ \\
\hline Osmiophilic rods & $(-)$ & $(-)$ & $(-)$ & $+t$ & + \\
\hline Nucleo-mitochondrial ratio & 11.2 & 10.2 & 14.3 & 15.7 & 16.7 \\
\hline Annulate lamellae & + & - & - & - & - \\
\hline Intercellular bridges & - & + & + & + & + \\
\hline Ribosomes & + & ++ & + & + & + \\
\hline Endoplasmic reticulum & + & + & + & + & $+t$ \\
\hline Golgi apparatus & $(+)$ & + & ++ & ++ & + \\
\hline Glycogen & - & \pm & \pm & \pm & \pm \\
\hline
\end{tabular}

clei of which were usually located at the periphery of the tubule. Thin cytoplasmic extensions of these cells were inserted between the spermatogonia. Not all the spermatogonia were completely surrounded, however, and two neighboring cells were sometimes found in direct contact with each other. The chromatin in the nucleus was diffuse and homogeneously "dusty" (Figs. 1, 2). Only one nucleolus was usually found in these spermatogonia, although two were sometimes identified under light microscopy. The nuclear membrane often had a undulated aspect (Fig. 1); there were few nuclear pores (Fig. 2).

Most of the mitochondria in the cytoplasm were gathered at one cellular pole (Figs. 1,2). They were spherical or slightly elongated with a clear matrix; the few cristae observed were oriented obliquely or roughly parallel to the mitochondrial wall (Figs. 1, 2). Dense granules $(80-130 \mathrm{~nm})$ were also found in the matrix (Figs. 1,2). Frequently associated with these mitochondria were various organelles: annulate lamellae (Fig. 1), Golgi cisternae and centrioles (Figs. 1, 2). The cytoplasm contained many ribosomes usually grouped in rosettes. Some dense material (cement) was associated with the mitochondria or found free ("nuages") in the cytoplasm (Fig. 2). Outside the basement membrane, the tubule was bound by an extremely thin but continuous wall (Fig. 2). Several stained bodies, which were possibly remnants of degenerating germ cell, were visible in Sertoli cells at the tubule apex. No organelle or material reacted to PTA or PA-TC-SP.

\section{Spermatogonia in cysts}

Immediately beneath the apex, the spermatogonia were grouped in cysts at different stages of development. As spermatogonial generations progressed, the chromatin became more dense and heterogeneous, especially after the G4 generation (Fig. 3). Peri- and inter-chromatin grains were also seen during the first spermatogonial generations. In early spermatogonia, the one or two nucleoli had the same structure and were the same size as in apical spermatogonia. In late spermatogonia, these nucleoli only appeared discretely, especially the pars fibrosa. As in GA, some of the mitochondria in the cytoplasm were grouped at one pole of the cell and associated with other organelles such as highly developed Golgi apparatus, intermitochondrial cement and "nuages" of dense material (Fig. 3). The mitochondrial matrix was darker than in GA. Some mitochondria had elongated considerably (up to $3 \mu \mathrm{m}$ ). During the progression of spermatogonial division, the area occupied by mitochondria remained approximately constant. The cytoplasm was densely occupied by ribosomes often grouped into rosettes. Small flagella were also identified. Spermatogonia at the edge of the cysts were apposed closely to the Sertoli cells. The intercellular spaces towards the center of the cyst were occupied by material that did not react to PTA, in contrast to that found around spermatocytes (see Fig. 4).

Only a few particles of glycogen could be identified in spermatogonia. Many intercellular bridges were identified between spermatogonia. Pyknotic cells and "stained bodies" were sometimes found inside these cysts and in Sertoli cells, respectively. In the proximal part of the tubules, large pyknotic patches surrounded by Sertoli cells were observed, indicating that entire cysts may degenerate.

\section{Spermatocytes}

The spermatocyte stage was characterized by more complex nuclear structures, with the formation of clumps of chroma- 

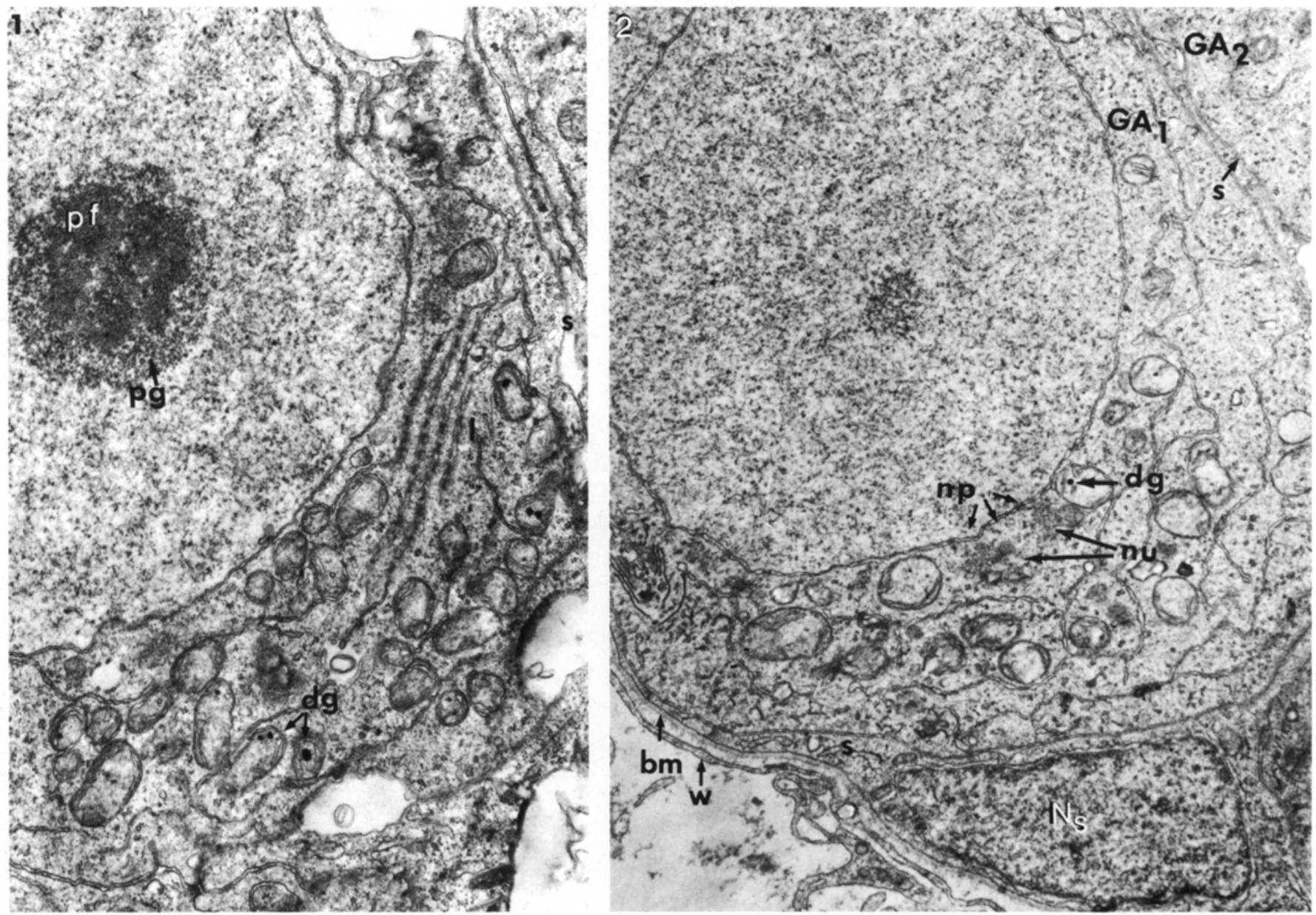

Fig. 1. Apical spermatogonia. Note the structure of the nucleolus [pars fibrosa ( $p f)$ surrounded by the pars granulosa $(p g)$ ], annulate lamellae $(l)$ and intramitochondrial dense granules $(d g) ; s$ layer of Sertoli cell cytoplasm. $\times 14000$

Fig. 2. Apical spermatogonia. $s$ Very thin cytoplasmic extension of a Sertoli cell; note its nucleus $\left(N_{s}\right)$ at bottom of micrograph. The extension is inserted between two spermatogonia, GA1 and $G A 2$. Outside the basement membrane (bm), the tubule is bound by a thin, continuous wall $(w) ; d g$ intramitochondrial dense granule; $n u$ "nuage" of dense material probably originating from the nucleus via the nuclear pore $(n p) . \times 10700$

tin and synaptinemal complexes. However, the chromatin appeared similar to that of the last spermatogonial generations (Fig. 3) and of the leptotene stage (Fig. 5), and thus these cells could only be identified by their larger nuclei and cysts. Typical synaptinemal complexes (Fig. 6) were distinct at the pachytene stage (Figs. 7-9) and were still seen at diplotene. Polycomplex-type organelles of similar structure were present during the formation of the metaphasic plate (Figs. 10, 11), although short, chromosomal cores still remained at this stage. Dense material reacting to PTA was abundant between the spermatocytes (Fig. 4) in contact with Sertoli cells and tended to accumulate between the spermatocytes (Fig. 4). Basement membranes and Golgi cisternae (Fig. 4) reacted strongly to PTA, the cisternae being highly developed in spermatocytes (Fig. 4). Numerous mitochondria were usually grouped at one pole of the cell, some being very elongated (Fig. 7). The mitochondrial matrix was relatively electron-dense, particularly during cell division, and the enlarged cristae were more numerous than in spermatogonial mitochondria. Spermatocyte mitochondria had dense granules and were sometimes asso- ciated with dense material (intermitochondrial cement) (Fig. 7). This dense material was also found in the form of "nuages" (Fig. 7). We observed a large variety of osmiophilic, fibrous structures in areas containing Golgi apparatuses and centrioles (Figs. 12,13). Individual cells often possessed many intercellular bridges (Fig. 9), some of which were considerably extended. Fig. 8 shows a long peduncle joining two widely separated cells. The microtubules observed in the peduncle could be either the remains of a division spindle or the cytoskeleton of the peduncle. This might also be an abnormal figure. Microtubules were observed on the outside of the nuclear envelope (Fig. 10). The nuclear envelope seemed to be duplicated. Apart from these structures, the spermatocytes had little endoplasmic reticulum but the cytoplasm was densely occupied by ribosomes often in the form of polyribosomes. Some "nuages" remained in spermatocytes in metaphase but there was no intermitochondrial cement. In spermatocyte and spermatogonial cysts, the Sertoli cells remained at the periphery of the cyst and, except for some very short extensions (Fig. 7), did not radiate towards the interior. 

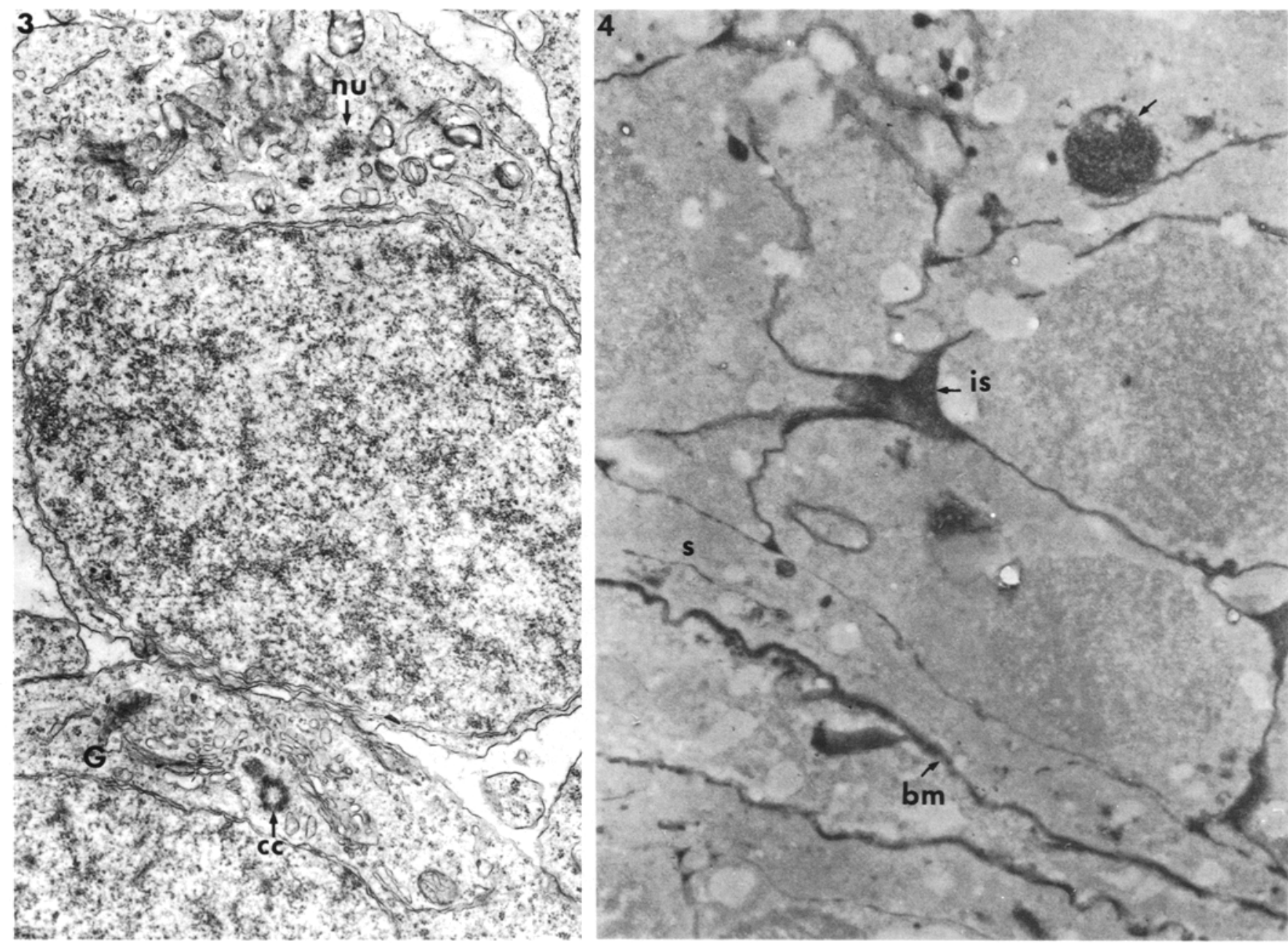

Fig. 3. Late spermatogonica. The organelles are concentrated at one pole of the cell. Note the mitochondria and "nuages" (nu) and Golgi cisternae $(G)$ around the centriolar complex $(c c)$. The chromatin is denser and more heterogeneous than in earlier stages. $x 18000$

Fig. 4. Spermatocytes in pachytene. Phosphotungstic acid staining. An area of reactive material is seen in the cytoplasm (arrows) and in the intercellular space (is); $b m$ basement membrane; $s$ Sertoli cell. $\times 9000$

\section{Discussion}

\section{Spermatogonia}

Spermatogonia show morphological changes throughout their numerous generations. The decrease in the size of the nucleus and the increase in chromatin density have already been noted in light microscopic studies (Vaupel 1929; Billard 1969a). However, the area occupied by mitochondria seems to remain constant. The higher concentration of mitochondria at one pole of the cell has also been seen using light microscopy (Vaupel 1929). In apical spermatogonia, mitochondrial cristae are rare (Porte and Follénius 1960), and annulate lamellae are present. Such structures have been described in spermatogonia in trout (Hurk et al. 1982), Pimephales notatus (in association with a "chromatoid body") (Schjeide et al. 1972), and in primary spermatocytes of Lycodontis afer (Mattei et al. 1967). The dense, osmiophilic material (free or associated with mitochondria), which might at least partly have resulted from a cytoplasmnucleus exchange, has been found in smaller amounts in Poecilia than in other teleosts (Clérot 1976; Bruslé 1982).

Intercellular bridges found between spermatogonia are characteristic of developing germinal cells (Fawcett et al. 1959). This incomplete type of spermatogonial division, discussed by Clérot (1971), concerns only cells committed to spermatogenesis (cells included in cysts in the present case) and not the free stem cells (GA) of the apex. However, intercellular bridges have been identified in the apex of guppy tubules (Billard and Fléchon 1969), the two cells thus joined constituting the beginning of a cyst developing in the apex itself. It should be noted that mitoses are not synchronous in the apex (Billard 1969a). Relationships between spermatogonia and Sertoli cells have been previously studied in $P$. reticulata (Billard $1970 \mathrm{~b}$ ). The present study confirms that spermatogonia, including those of the apex, are never in contact with the basement membrane; they are always separated from it by at least one layer of Sertoli cells. The presence of "stained bodies" in apical Sertoli cells indicates that stem spermatogonia degenerate. During at least the first spermatogonial generations, entire cysts may also degenerate. We could not determine the extent of this degeneration in the present study but previous work (Billard 1969a) has evaluated the total number of these cysts at $2.5 \%$. Degeneration should considerably reduce the 

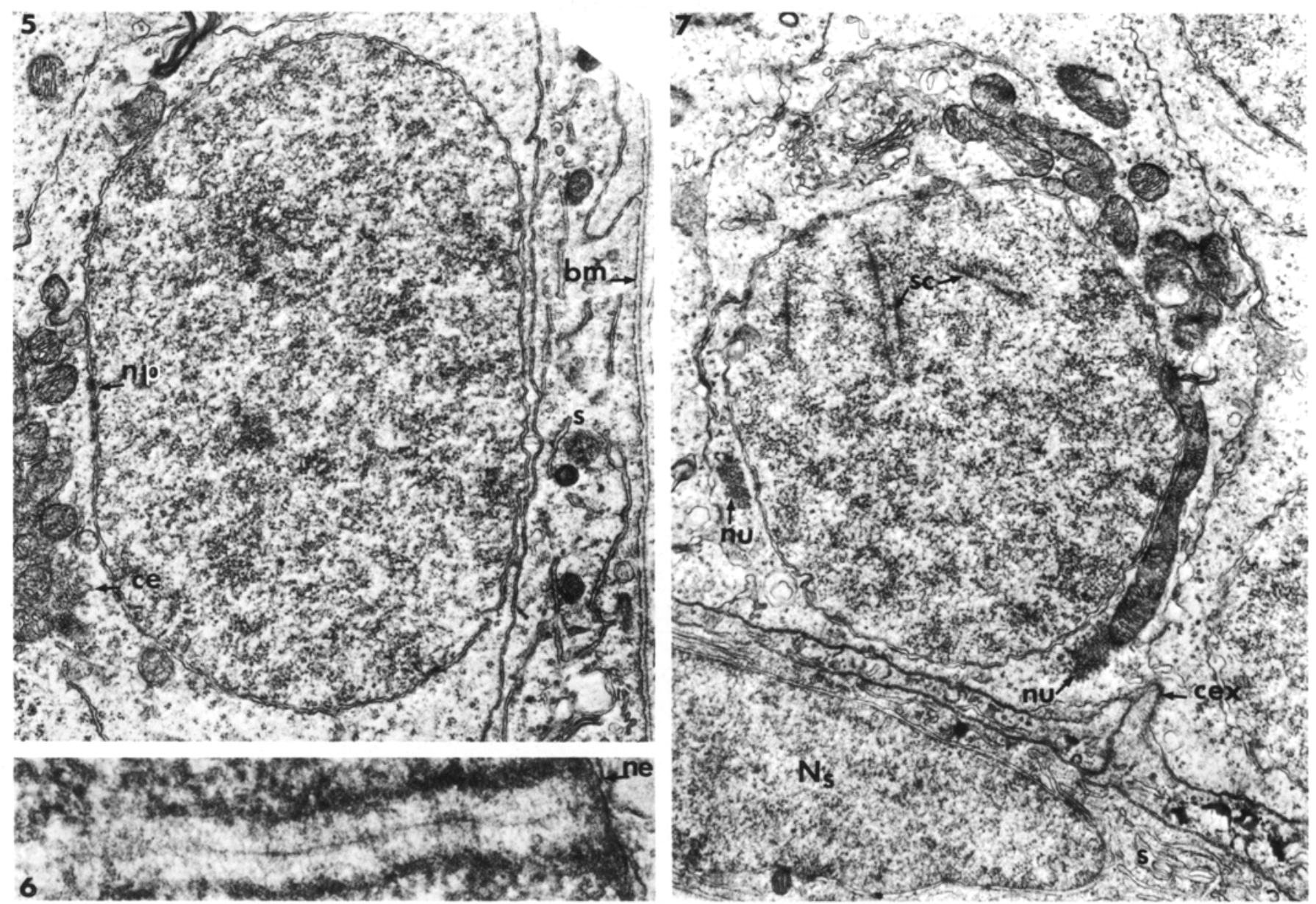

Fig. 5. Leptotene spermatocyte showing the chromatin becoming denser and a group of mitochondria with cement (ce). $n p$ nuclear pore; $b m$ basement membrane; $s$ Sertoli cell. $\times 13000$

Fig. 6. Synaptinemal complex attached to the nuclear envelope $(n e)$ of a pachytene spermatocyte. $\times 69000$

Fig. 7. Pachytene spermatocyte I at the edge of a cyst. Note the synaptinemal complexes (sc) in the nucleus. Small cytoplasmic extensions $(c e x)$ radiate from the Sertoli cells $(s)$ towards the interior of the cyst. $N_{s}$ Sertoli cell nucleus; $n u$ "nuage". $\times 12000$

effectiveness of spermatogenesis, although the efficiency of this process appears to be relatively good $(65 \%)$ according to a light microscopy study by Billard (1969a). The morphological differences between the first (G1-G7) and last (G8-G14) spermatogonial generations correspond to physiological differences observed after hypophysectomy (Billard $1969 \mathrm{~b}$ ) and methallibure (Billard et al. 1970) or parathion (Billard and de Kinkelin 1970) treatment, the last generations being highly dependent on the presence of pituitary gonadotropin and more sensitive to micropollutants than the first generations.

In conclusion, apical spermatogonia are little differentiated and morphologically independent, and their divisions are not synchronous. These spermatogonia in guppy appear to correspond to type A spermatogonia in mammals, as shown by Lofts (1968) and Billard (1969a) in other teleosts and by Stanley (1966) and Holstein (1968) in selachians. Although spermatogonia in the first cysts (G1 to G3) retain some of the morphological characteristics of GA, their location inside well-organized cysts indicates that they are committed irreversibly to spermatogenesis, i.e. that they are homologous to type B spermatogonia and not to stem cells.

\section{Spermatocytes}

The structure of the nuclear chromatin of spermatocytes is characterized by the appearance of many clumps of chromatin and the synaptinemal complex. The latter, identified by Fawcett (1956), takes a variety of forms (see review by Westergaard and Wettstein 1972). According to Nebel (1960), the structures identified during metaphase I (Figs. 10-11) can also be considered as synaptinemal complexes or as derivations of a polycomplex type (Oakley and Jones 1982); Jones (1962) has found similar structures in nucleoli.

Contrary to the higher vertebrates (André 1962), there is little mitochondrial transformation in spermatocytes and spermatids of guppy (Billard 1970a). The mitochondrial groupings associated with intermitochondrial cement and "nuages" (also reported in Gasterosteus by Follénius 1965) have been found here up to metaphase, an unusual feature for teleosts (Bruslé 1982). The diversification of organelles in late spermatocytes (Figs. 12,13), especially the centriolar transformation described in this species (Billard 1970a), may be related to the complexity of spermiogenesis. The 

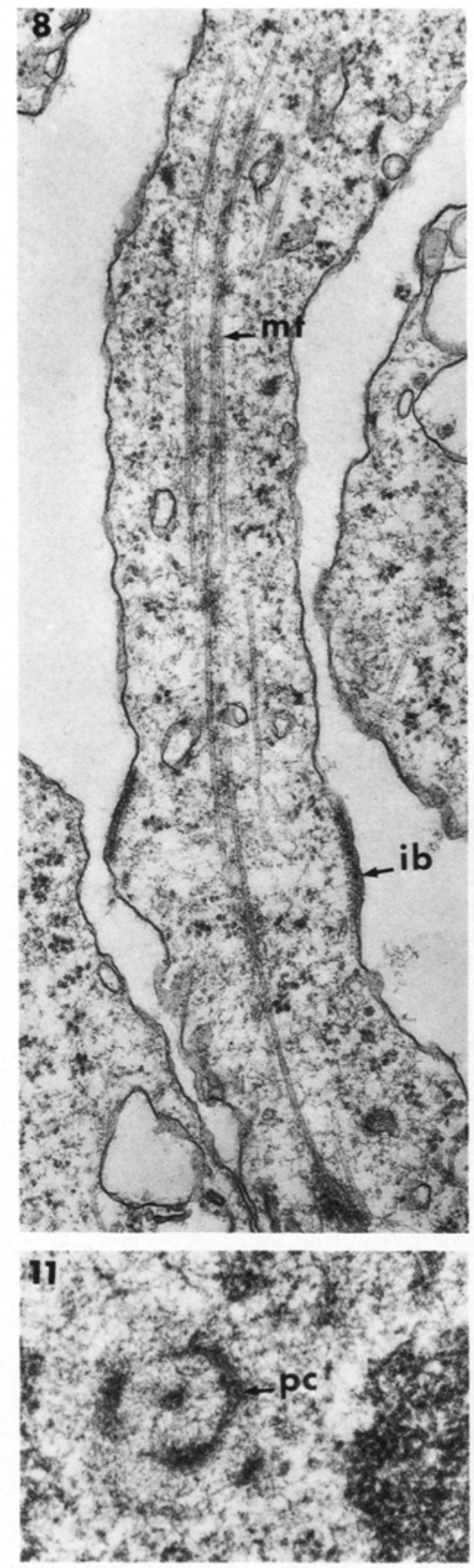
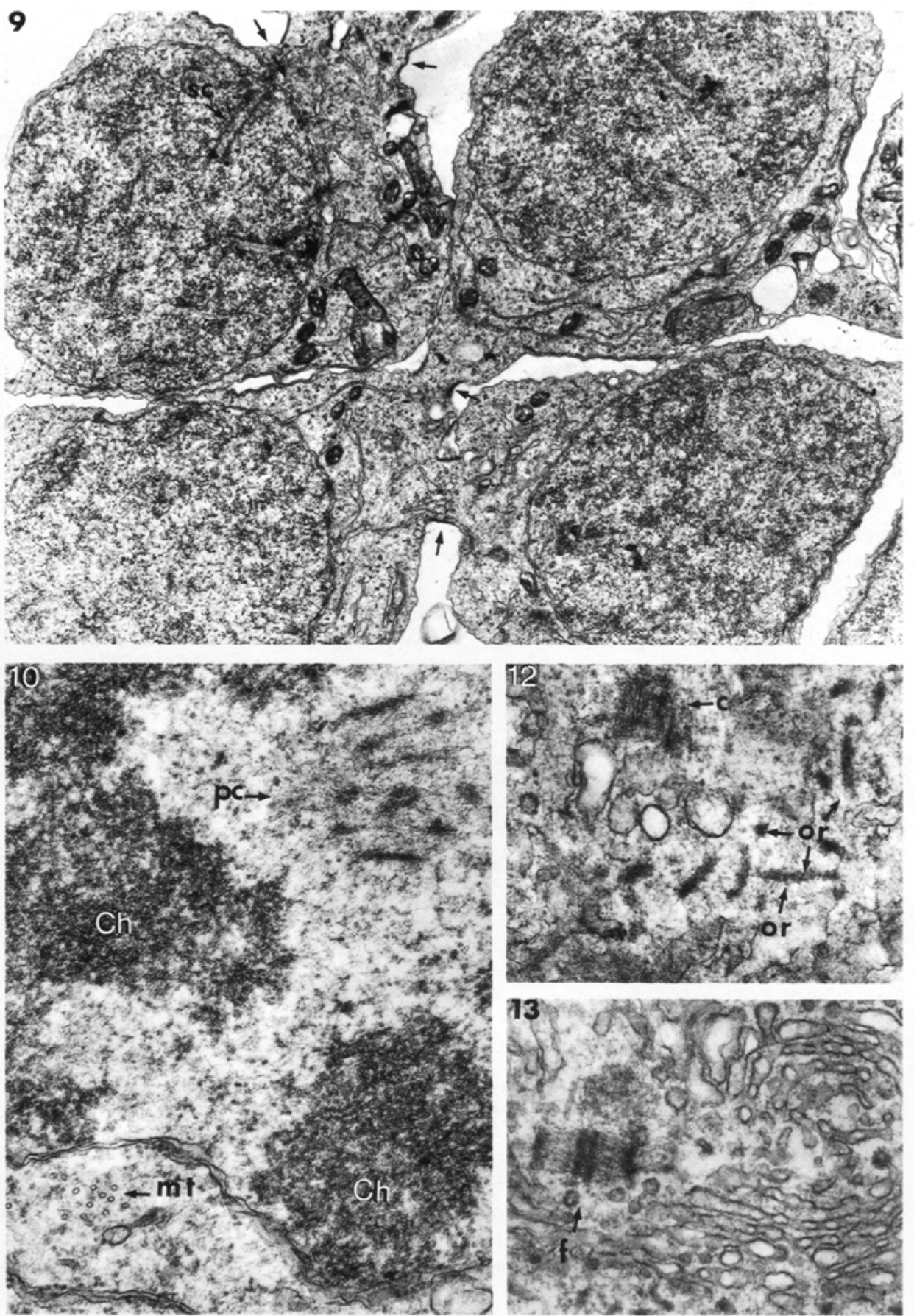
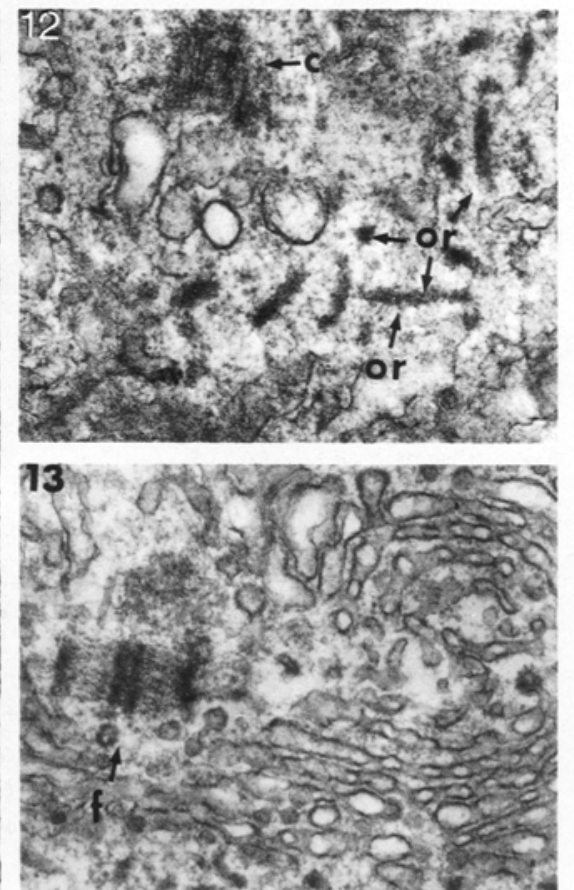

Fig. 8. Intercellular bridge $(i b)$ on a long peduncle linking two spermatocytes I that are far apart; $m t$ microtubule. $\times 30000$

Fig. 9. Pachytene spermatocytes $I$ in the center of a cyst connected to each other by cytoplasmic bridges (arrows). sc synaptinemal complex. $\times 10000$

Fig. 10. Spermatocyte $I$ in metaphase $I$. The fibrous structure at top right is probably a remnant of a polycomplex-type synaptinemal complex (pc) (see Oakley and Jones 1982). At the bottom, microtubules (mt) outside the nuclear envelope are organized into bundles. Ch chromosome $\times 30000$

Fig. 11. Another section of the polycomplex-type structure $(p c)$ seen in Fig. $10 . \times 30000$

Fig. 12. Spermatocyte I. Note the osmiophilic rods (or) in the vicinity of the centriolar complex $(c) . \times 30000$

Fig. 13. Spermatocyte I. Golgi cisternae and a fibrous structure $(f) . \times 40000$ 
intercellular bridges linking spermatocytes can be easily identified, perhaps because of the prominent spaces between the cells. As in spermatogonia, the presence of these bridges has often been reported between spermatocytes whether they occur in cysts (Clérot 1971; Russo and Pisano 1973) or not (Dym and Fawcett 1971). Fig. 9 shows that one cell may have several cytoplasmic bridges; this would suggest that the cell retains these links with sister-cells over several divisions. Thus, all the cells in a cyst may remain in contact with each other by these bridges, as proposed by Clérot (1971).

The carbohydrate material secreted into the intercellular space inside the cysts is readily apparent in spermatocyte cysts (Fig. 4) and in round spermatid cysts (Billard, unpublished data); it might have a trophic function. This accumulation might also result from the establishment of the bloodtestis barrier in meiotic and postmeiotic cysts due to the development of zona occludens (Marcaillou and Szöllösi 1980). This barrier may prevent the intercystic material from leaving the cyst. The trophic relationships between Sertoli and germinal cells are not clear; they could occur by way of the intercellular material. Flickinger and Fawcett (1967) have suggested that germinal cells move. If so, they may regularly visit the edge of the cyst and become closely apposed to the Sertoli cells. The presence of long peduncles between two cells (Fig. 8) would agree with this hypothesis. However, some intercellular exchange may take place via the cytoplasmic bridges.

The presence of microtubules on the outside of the nuclear membrane suggests that, if these microtubules play a role in the formation of the division spindle, they are in place before the nuclear envelope disappears. This membrane would disappear first at the centriolar region, but still remain in place laterally while the division spindle is present and the metaphasic plate forms.

\section{Structure of the tubule}

The present study shows that at least the anterior part of the tubule is covered by a thin layer of cytoplasm that lies outside the basement membrane and seems continuous, contrary to the description of the lobular type (unrestricted) testis given by Grier et al. (1980).

Acknowledgements. We wish to thank Alice Daifuku for editing the English manuscript and Denise Huneau and Anne-Marie Escaffre for technical assistance. We are grateful to Dr. M. Loir for helpful criticism and discussion.

\section{References}

André $J$ (1962) Contribution à la connaissance du chondriome. Etude de ses modifications ultrastructurales pendant la spermatogenèse. J Ultrastruct Res Suppl 3:1-185

Billard R (1969a) La spermatogenèse du Poecilia reticulata. I Estimation du nombre de générations goniales et rendement de la spermatogenèse. Ann Biol Anim Biochim Biophys 9:251-271

Billard R (1969 b) Hypophysectomie et spermatogenèse chez Poecilia reticulata. CR Acad Sci Paris 268:1856-1859

Billard R (1970a) La spermatogenèse chez Poecilia reticulata. IV - La spermiogenèse. Etude structurale. Ann Biol Anim Biochim Biophys 10:493-510

Billard R (1970b) La spermatogenèse de Poecilia reticulata. III -Ultrastructure des cellules de Sertoli. Ann Biol Anim Biochim Biophys 10:37-50

Billard R, Fléchon JE (1969) Spermatogonies et spermatocytes fla- gellés chez Poecilia reticulata (poisson Téléosteen Cyprinodontiforme). Ann Biol Anim Biochim Biophys 9:281-286

Billard R, De Kinkelin P (1970) Stérilisation des testicules de guppies par des doses non léthales de parathion. Ann Hydrobiol 1:91-99

Billard R, Breton B, Jalabert B (1970) Inhibition de la spermatogenèse du guppy (Poisson Cyprinodontidae) par le méthallibure. Ann Biol Anim Biochim Biophys 10:511-515

Billard R, Breton B, Jalabert B (1973) Le glycogène au cours de la formation des spermatozoïdes et de leur transit dans le tractus génital femelle chez le guppy (poisson Poecilidae). Ann Biol Anim Biochim Biophys 11:167-174

Billard R, Fostier A, Weil C, Breton B (1982) Endocrine control of spermatogenesis in teleost fish. Can J Fish Aquat Sci $39: 65-79$

Bruslé S (1982) Contribution à la connaissance de la sexualité des poissons téléostéens marins gonochoriques (Mugilidés) et hermaphrodites (Serranidés). Thèse Doct Sci Univ Perpignan, 360 $\mathrm{pp}$

Clerot JC (1971) Les ponts intercellulaires du testicule de gardon: organisation syncitiale et synchronie de la différenciation des cellules germinales. J Ultrastruct Res 37:690-703

Clerot JC (1976) Les groupements mitochondriaux des cellules germinales des poissons téléostéens Cyprinidés. I - Etude ultrastructurale. J Ultrastruct Res 54:461-475

Dulzetto F (1933) La struttura del testicolo di Gambusia holbrookii e la sua evoluzione in rapporto con la sviluppo del gonopodia. Arch Zool Ital 19:405-437

Dym M, Fawcett W (1971) Further observations on the numbers of spermatogonia, spermatocytes and spermatids connected by intercellular bridges in the mammalian testis. Biol Reprod $4: 195-215$

Fawcett DW (1956) The fine structure of chromosomes in the meiotic prophase of vertebrate spermatocytes. J Biophys Biochem Cytol 2:403

Fawcett DW, Ito S, Slautterback D (1959) The occurrence of intercellular bridges in groups of cells exhibiting synchronous differentiation. J Biophys Biochem Cytol 5:453-460

Flickinger C, Fawcett DW (1967) Junctional specializations of Sertoli cells in the seminiferous epithelium. Anat Rec 158:207-222

Follénius E (1965) Cytologie fine des spermatocytes de l'Epinoche (Gasterosteus aculeatus): échanges nucléo-cytoplasmiques et formation d'amas de mitochondries. CR Acad Sci Paris $261: 4849-4852$

Grier HJ (1975a) Aspects of germinal cyst and sperm development in Poecilia latipinna (Teleostei Poeciliidae). J Morphol $146: 229-250$

Grier HJ (1975b) Spermiogenesis in the teleost Gambusia affinis with particular reference to the role played by microtubules. Cell Tissue Res 165:89-102

Grier HJ (1981) Cellular organization of the testis and spermatogenesis in fishes. Am Zool 21:345-357

Grier HJ, Linton JR, Leatherland JF, de Vlaming VL (1980) Structural evidence for two different testicular types in teleost fishes. Am J Anat 159:331-345

Holstein AF (1968) Zur trage der lokalen Steuerung der Spermatogenese beim Dornhai (Squalus acanthias L.). Z Zellforsch 93:265-281

Hurk R van Den (1973) The localisation of steroidogenesis in the testes of oviparous and viviparous teleosts. Proc K Ned Akad Wet Ser C 76:270-279

Hurk R van Den, Lambert JGD, Peute J (1982) Steroidogenesis in the gonads of rainbow trout fry (Salmo gairdneri) before and after the onset of gonadal sex differentiation. Reprod Nutr Dev 22:413-425

Jones P (1962) Paramitotic granulation and ribosome bodies in erythroblasts. J Ultrastruct Res 7:308-315

Lofts B (1968) Patterns of testicular activity. In: Barrington E, Jorgensen CB (eds) Perspectives in endocrinology. Acad Press London, New York, pp 236-304

Marcaillou C, Szöllösi A (1980) The blood testis barrier in a nema- 
tode and a fish: a generalizable concept. J Ultrastruct Res 70:128-136

Mattéi C, Boisson C, Mattéi X (1967) Présence de lamelles annelées dans les spermatocytes de "Lycodontis afer" (Muraenidae). CR Soc Biol 161:1761-1763

Nebel BR (1960) On the structure of mammalian chromosomes during spermatogenesis and after radiation with special reference to cores. Quat Congr Int Microsc Electron, Berlin 1958

Oakley HA, Jones GH (1982) Meiosis in Mesostoma ehrenbergii ehrenbergii (Turbellaria, rhabdocoela). I-Chromosome pairing, synaptonemal complexes and chiasma localization in spermatogenesis. Chromosoma $85: 311-322$

Porte A, Follénius E (1960) La spermiogenèse chez Lebistes reticulatus. Etude au microscope électronique. Bull Soc Zool Fr $85: 82-88$

Roosen-Runge EC (1977) The process of spermatogenesis in ani- mals. Cambridge Univ. Press, Cambridge, London, New York, Melbourne

Russo J, Pisano A (1973) Some ultrastructural characteristics of Platipoecilus maculatus spermatogenesis. Boll Zool 40:201-207

Schjeide A, Nicholls T, Graham G (1972) Annulate lamellae and chromatoid bodies in the testes of a cyprinid fish (Pimephales notatus). Z Zellforsch 129:1-10

Stanley HP (1966) The structure and the development of the seminiferous follicle in Scyliorhinus caniculus and Torpedo marmorata (Elasmobranchii). Z Zellforsch 75:453-468

Vaupel J (1929) The spermatogenesis of Lebistes reticulatus. J Morphol 47:555-587

Westergaard M, Wettstein von D (1972) The synaptinemal complex. Ann Rev Gen 6:71-110

Accepted May 3, 1984 